\title{
Unusual association of NDM-1 with KPC-2 and armA among Brazilian Enterobacteriaceae isolates
}

\author{
M.G. Quiles ${ }^{1}$, T.T. Rocchetti ${ }^{1}$, L.C. Fehlberg ${ }^{1}$, E.J.U. Kusano ${ }^{2}$, A. Chebabo ${ }^{2}$, R.M.G. Pereira ${ }^{2}$, \\ A.C. Gales ${ }^{1}$ and A.C.C. Pignatari ${ }^{1,2}$ \\ ${ }^{1}$ Laboratório Especial de Microbiologia Clínica, Departamento de Medicina, \\ Universidade Federal de São Paulo, São Paulo, SP, Brasil \\ ${ }^{2}$ Laboratório Diagnósticos da América, DASA, São Paulo, SP, Brasil
}

\begin{abstract}
We report the microbiological characterization of four New Delhi metallo- $\beta$-lactamase-1 (b/a NDM-1 $_{\text {- }}$-producing Enterobacteriaceae isolated in Rio de Janeiro, Brazil. bla $a_{\mathrm{NDM}-1}$ was located on a conjugative plasmid and was associated with Klebsiella pneumoniae carbapenemase-2 (b/a KPC-2) or aminoglycoside-resistance methylase (armA), a 16S rRNA methylase not previously reported in Brazil, in two distinct strains of Enterobacter cloacae. Our results suggested that the introduction of bla $\mathrm{NDM}_{1}$ in Brazil has been accompanied by rapid spread, since our isolates showed no genetic relationship.
\end{abstract}

Key words: Enterobacteriaceae; Carbapenem-resistance; Carbapenemases; Methylase

\section{Introduction}

Antimicrobial resistance is a growing global challenge to human health. The New Delhi metallo- $\beta$-lactamase (NDM), an acquired class $B$ carbapenemase, has gained public attention due to its rapid worldwide dissemination. bla $a_{\mathrm{NDM}-1}$ was first identified in Klebsiella pneumoniae and Escherichia coli from India and Pakistan in 2008 (1,2). Subsequent studies reported NDM-1 from hospitals located in other Indian cities, as well as from drinking water and seepage water in New Delhi (3). To date, NDM-1-producing isolates have been reported in more than 50 countries $(1,4)$. While many of the patients carrying NDM-1-producing strains had a history of hospitalization in India, Pakistan or Bangladesh, others had simply travelled to this region, which may indicate community acquisition of NDM-producing bacteria by ingestion of contaminated water and/or food. In Brazil, the first report of NDM-1 occurred in July 2013 in a Providencia rettgeri strain isolated from Rio Grande do Sul (5). In this study, we characterized four Enterobacteriaceae clinical isolates that were NDM-1 producing and were recovered at different hospitals in Rio de Janeiro, Brazil.

\section{Material and Methods}

Four carbapenem-resistant Enterobacteriaceae strains were isolated from various sites from four different patients admitted at four different hospitals located in two cities in the state of Rio de Janeiro between September and October 2013. These isolates were identified as $P$. rettgeri and Enterobacter cloacae (ECL) $(n=3)$ using a Vitek ${ }^{(\mathbb{R}} 2$ Compact automated system (bioMérieux Clinical Diagnostics, France). These isolates were resistant to carbapenems, with a minimum inhibitory concentration $(\mathrm{MIC}) \geqslant 2 \mu \mathrm{g} / \mathrm{mL}$ for imipenem or meropenem and an MIC $\geqslant 1 \mu \mathrm{g} / \mathrm{mL}$ for ertapenem. Because of that, they were screened for carbapenemase production by testing commercially available disks containing carbapenems with and without EDTA $(0.1 \mathrm{M})$, cloxacillin $(75 \mathrm{mg} / \mathrm{mL})$ or phenylboronic acid $(40 \mathrm{mg} / \mathrm{mL})$, as recommended by the National Health Surveillance Agency (ANVISA) technical guidelines (6).

Since the diameter-zone difference between the carbapenem/EDTA and carbapenem disks was $\geqslant 5 \mathrm{~mm}$, these strains were screened as possible metallo- $\beta$-lactamase $(\mathrm{MBL})$ producers and referred to the Laboratório Especial de Microbiologia Clínica, UNIFESP, São Paulo, SP, Brazil for further molecular characterization. The Enterobacteriaceae strains were re-identified at the species level by matrixassisted laser desorption ionization time-of-flight (MALDI-ToF) mass spectroscopy (Bruker Daltonics, Germany), using the Biotyper 3.0 software (Bruker Daltonics, Germany), and $16 S$ rRNA DNA sequencing.

Correspondence: M.G. Quiles: <m.quiles@unifesp.br>.

Received May 27, 2014. Accepted October 13, 2014. First published online December 5, 2014. 
The antimicrobial susceptibility profile was performed and interpreted by the Clinical and Laboratory Standards Institute (CLSI) broth microdilution guidelines (7), except for polymyxin $\mathrm{B}$, for which the European Committee on Antimicrobial Susceptibility Testing (EUCAST) (8) breakpoints were applied. The MBL phenotype was investigated by the MBL imipenem/imipenem-inhibitor (IP/IPI) E-test method (AB Biodisk, Sweden). Detection of the following encoding genes, bla $a_{\mathrm{NDM}}, b / a_{\mathrm{KPC}}, b / a_{\mathrm{GES}}, b / a_{\mathrm{SPM}}, b / a_{\mathrm{GIM}}$,

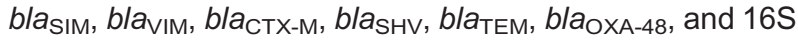
rRNA methylase genes, rmtA, rmtB, rmtC, rmtD, rmtG, armA and $n p m A$, was carried out by PCR followed by DNA sequencing ( $A B I$ sequencer, Applied Biosystems, USA).

Clonal relatedness among ECL isolates was evaluated by pulsed field gel electrophoresis (PFGE) using the Spel restriction endonuclease (New England BioLabs, USA). The band patterns were analyzed by visual inspection, applying the criteria established by Tenover et al. (9). Conjugation and transformation experiments were performed using $E$. coli J53 (LacZ ${ }^{-}$Nall $^{r}$ Rif $\left.^{r}\right)$ and E. coli DH5 $\alpha$, respectively, as recipient strains. Transconjugants were selected on MacConkey agar, using imipenem $(0.5 \mu \mathrm{g} / \mathrm{mL})$ and azide $(150 \mu \mathrm{g} / \mathrm{mL})$. Plasmids and whole genome DNA were extracted from the strains and from E. coli J53 by the Kieser method (10) and with a QIAamp DNA Mini Kit (Qiagen, Germany), respectively, and analyzed using a $0.8 \%$ agarose gel. A replicon-based PCR typing of plasmid incompatibility groups (Inc/rep) was performed using previously published protocols $(11,12)$ with 5 multiplex and 6 single reactions recognizing the $\mathrm{FIA}$, FIB, FIC, HI1, HI2, I1-ly, L/M, N, P, W, T, A/C, K, B/O, X, Y, F, FIIA, and Q replicons.

\section{Results}

The results of this study are summarized in Table 1. The initial identification of bacterial species was confirmed, as well as the MBL phenotype, by the E-test. All

Table 1. Molecular and phenotypic characterization of NDM-1-producing isolates in Rio de Janeiro, Brazil.

\begin{tabular}{|c|c|c|c|c|c|c|c|}
\hline Strains & $\begin{array}{l}\text { P. rettgeri } \\
\text { E132 }\end{array}$ & $\begin{array}{l}\text { E. coli J53+ } \\
\text { pECLE132 }\end{array}$ & $\begin{array}{l}\text { E. cloacae } \\
\text { E133 }\end{array}$ & $\begin{array}{l}\text { E. cloacae } \\
\text { E134 }\end{array}$ & $\begin{array}{c}\text { E. coli J53+ } \\
\text { pECLE134 }\end{array}$ & $\begin{array}{l}\text { E. cloacae } \\
\text { E135 }\end{array}$ & $\begin{array}{c}\text { E. coli } \\
\text { J53 }\end{array}$ \\
\hline Site of isolation & Catheter & - & Urine & Blood & - & Ascitic fluid & - \\
\hline PFGE pattern & - & - & A & B & - & $\mathrm{C}$ & - \\
\hline \multicolumn{8}{|l|}{$\operatorname{MIC}(\mu \mathrm{g} / \mathrm{mL})^{*}$} \\
\hline IMI & 32 & 8 & 16 & 16 & 32 & 8 & 0.06 \\
\hline IMI/AC & 32 & 8 & 16 & 16 & 16 & 8 & - \\
\hline Mero & 32 & 8 & 32 & 12 & 64 & 4 & 0.13 \\
\hline MERO/AC & 32 & 8 & 32 & 16 & 16 & 32 & - \\
\hline Erta & 256 & 64 & 128 & 256 & 128 & 16 & 0.01 \\
\hline Erta/AC & 128 & 32 & 256 & 256 & 128 & 128 & - \\
\hline Poly B & $>128$ & $<0.125$ & 0.25 & 0.25 & $<0.25$ & $<0.25$ & $<0.25$ \\
\hline CEF & 256 & 128 & 512 & $>512$ & 256 & 64 & 0.06 \\
\hline Cipro & $>256$ & 0.016 & $>32$ & 64 & 0.016 & 0.032 & 0.008 \\
\hline Levo & $>256$ & $<0.25$ & 64 & 16 & $<0.25$ & $<0.25$ & 0.125 \\
\hline CAZ & $>512$ & $>512$ & $>512$ & $>512$ & $>512$ & $>512$ & 0.125 \\
\hline Tige & 0.5 & 0.06 & 0.25 & 1 & 0.06 & 0.25 & 0.25 \\
\hline CRO & 512 & 512 & $>512$ & $>512$ & $>512$ & 512 & - \\
\hline CFL & $>512$ & $>512$ & $>512$ & $>512$ & $>512$ & $>512$ & - \\
\hline Genta & 0.25 & 2 & $>128$ & 64 & 1 & 1 & 0.125 \\
\hline Amica & 4 & 2 & $>256$ & 4 & 2 & 4 & $<2$ \\
\hline CTX & $>512$ & $>512$ & $>512$ & $>512$ & $>512$ & $>512$ & 0.06 \\
\hline MBL E-test & + & + & + & + & + & + & - \\
\hline Inc/rep typing & $\mathrm{HI} 2$ and $\mathrm{P}$ & $\mathrm{P}$ & $\mathrm{HI} 2$ and $\mathrm{W}$ & $\mathrm{P}$ and $\mathrm{N}$ & $\mathrm{P}$ & $* *$ & - \\
\hline bla genes & $\begin{array}{l}\text { NDM-1 } \\
\text { and } \\
\text { TEM-1 }\end{array}$ & NDM-1 & $\begin{array}{c}\text { NDM-1, } \\
\text { TEM-1, } \\
\text { CTX-M-15 } \\
\text { and armA }\end{array}$ & $\begin{array}{c}\text { NDM-1, } \\
\text { KPC-2, } \\
\text { TEM-1 and } \\
\text { CTX-M-15 }\end{array}$ & NDM-1 & $\begin{array}{l}\text { NDM-1, } \\
\text { TEM-1 and } \\
\text { CTX-M-15 }\end{array}$ & \\
\hline
\end{tabular}

NDM-1: New Delhi metallo- $\beta$-lactamase-1; PFGE: pulsed field gel electrophoresis; IMI: imipenem; AC: clavulanic acid; Mero: meropenem; Erta: ertapenem; Poly B: polymixyn B; CEF: cefepime; Cipro: ciprofloxacin; Levo: levofloxacin; CAZ: ceftazidime; Tige: tigecycline; CRO: ceftriaxone; CFL: cephalothin; Genta: gentamicin; Amica: amikacin; CTX: cefotaxime; MBL: metallo- $\beta$-lactamase * Minimum inhibitory concentrations (MICs) were determined by agar dilution [Clinical and Laboratory Standards Institute (CLSI) 2013].

** The E135 sample tested negative for all plasmid incompatibility groups. 
isolates were resistant to broad-spectrum cephalosporins, ertapenem, imipenem, and meropenem. The ECL isolates were susceptible to polymyxin $\mathrm{B}$, but the $P$. rettgeri isolate (\#E132) was resistant to this agent, as expected. The presence of bla $a_{\mathrm{NDM}-1}$ and bla $\mathrm{TEM}_{\mathrm{TE}-1}$ was confirmed in all isolates. All ECL isolates carried bla $\mathrm{CTTX}_{\mathrm{C}-\mathrm{M}-15}$ and possessed different PFGE patterns. Co-occurrence of bla $a_{\mathrm{NDM}-1}$ with armA or with bla $a_{\mathrm{KPC}-2}$ genes was detected in two distinct ECL strains, E134 and E133, respectively. The transference of bla NDM-1 $_{1}$ to a recipient strain was achieved for strains $\mathrm{E} 132$ and E134, suggesting that this gene was probably located on a $\sim 230 \mathrm{~kb}$ conjugative plasmid that belonged to the Inc/rep $P$ type. The transference of bla $\mathrm{NDM}_{\mathrm{N}-1}$ by conjugation failed for the remaining isolates. Hybridization revealed that the bla $a_{\mathrm{KPC}-2}$ gene was located on the chromosome of the E134 isolate. This finding explained why repetitive attempts to transfer $b / a_{K P C}-2$ by conjugation have failed. Electroporation experiments were unsuccessful. Transconjugant strains showed the same elevation of carbapenem MICs as exhibited by donor strains.

\section{Discussion}

Carbapenems are the most frequently used antibiotics for the treatment of multidrug-resistant Enterobacteriaceae infections. Few therapeutic options are available for treatment of carbapenemase-producing Enterobacteriaceae, especially for Providencia spp. isolates that are intrinsically resistant to polymyxins.

Although bla NDM-1 $_{1}$ has been described in Brazil recently (5), we observed that reports by clinical laboratories of isolates possessing this enzyme became more frequent

\section{References}

1. Nordmann P, Poirel L, Walsh TR, Livermore DM. The emerging NDM carbapenemases. Trends Microbiol 2011; 19: 588-595, doi: 10.1016/j.tim.2011.09.005.

2. Kumarasamy KK, Toleman MA, Walsh TR, Bagaria J, Butt F, Balakrishnan $\mathrm{R}$, et al. Emergence of a new antibiotic resistance mechanism in India, Pakistan, and the UK: a molecular, biological, and epidemiological study. Lancet Infect Dis 2010; 10: 597-602, doi: 10.1016/S1473-3099(10)70143-2.

3. Walsh TR, Weeks J, Livermore DM, Toleman MA. Dissemination of NDM-1 positive bacteria in the New Delhi environment and its implications for human health: an environmental point prevalence study. Lancet Infect Dis 2011; 11: 355-362, doi: 10.1016/S1473-3099(11)70059-7.

4. Nordmann P, Dortet L, Poirel L. Carbapenem resistance in Enterobacteriaceae: here is the storm! Trends Mol Med 2012; 18: 263-272.

5. Carvalho-Assef AP, Pereira PS, Albano RM, Beriao GC Chagas TP, Timm LN, et al. Isolation of NDM-producing Providencia rettgeri in Brazil. J Antimicrob Chemother 2013; 68: 2956-2957, doi: 10.1093/jac/dkt298.

6. Agência Nacional de Vigilância Sanitária. ANVISA. Medidas de prevenção e controle de infecções por Enterobactérias after the implementation of the ANVISA technical standards. This technical document recommends MBL screening of all carbapenem-resistant Enterobacteriaceae, using carbapenem plus carbapenem/EDTA.

Previous studies detected the association of NDM-1 with other carbapenemases and methylase genes (13-16). In Brazil, Bueno and colleagues (16) recently described the coproduction of the rmtG methylase in $K$. pneumoniae isolates that carried b/a $a_{\mathrm{KPC}-2}$ and bla $a_{\mathrm{CTX}-\mathrm{M}-15}$. To the best of our knowledge, this study is the first to describe the association of bla $a_{\mathrm{NDM}-1}$ and bla $\mathrm{KPC}_{\mathrm{KP}}$ in Brazilian isolates, as well as the association of bla NDM-1 $_{1}$ with armA, a 16S rRNA methylase gene. Moreover, this is the first report of armA among Brazilian clinical isolates.

The emergence of $b / a_{\mathrm{NDM}-1}$ in association with other resistance genes demonstrates the rapid evolution of bacteria and the ability to acquire and keep different resistance genes. This fact is worrisome because the antimicrobial options available for treatment of these infections are decreasing. The distinct patterns observed among ECL clinical isolates suggest that bla $a_{N D M-1}$ had spread silently in the hospitals.

\section{Acknowledgments}

The authors would like to thank Marcus Vinícius Gaspari and Ana Carolina R. Silva (Laboratório Especial de Microbiologia Clínica, UNIFESP) for their technical assistance with the PFGE and MALDI-ToF assays. M.G. Quiles is a PhD student financially supported by CAPES. A.C. Gales and A.C.C. Pignatari are researchers from CNPq. multiresistentes. Nota Técnica N. 1/2013. http://portal.anvisa. gov.br. Accessed January 20, 2014

7. Clinical and Laboratory Standards Institute. Performance standards for antimicrobial susceptibility testing. 23rd Informational Supplement. Wayne: Clinical and Laboratory Standards Institute (M100-S23); 2014.

8. European Committee on Antimicrobial Susceptibility Testing. EUCAST. Breakpoint tables for interpretation of MICs and zone diameters. http://www.eucast.org/clinical_ breakpoints/. Accessed January 20, 2014.

9. Tenover FC, Arbeit RD, Goering RV, Mickelsen PA, Murray $\mathrm{BE}$, Persing $\mathrm{DH}$, et al. Interpreting chromosomal DNA restriction patterns produced by pulsed-field gel electrophoresis: criteria for bacterial strain typing. J Clin Microbiol 1995; 33: 2233-2239

10. Kieser T. Factors affecting the isolation of CCC DNA from Streptomyces lividans and Escherichia coli. Plasmid 1984; 12: 19-36, doi: 10.1016/0147-619X(84)90063-5.

11. Carattoli A, Bertini A, Villa L, Falbo V, Hopkins KL, Threlfall EJ. Identification of plasmids by PCR-based replicon typing. J Microbiol Methods 2005; 63: 219-228, doi: 10.1016/ j.mimet.2005.03.018. 
12. Gotz A, Pukall R, Smit E, Tietze E, Prager R, Tschape H, et al. Detection and characterization of broad-host-range plasmids in environmental bacteria by PCR. Appl Environ Microbiol 1996; 62: 2621-2628.

13. Shoma S, Kamruzzaman M, Ginn AN, Iredell JR, Partridge SR. Characterization of multidrug-resistant Klebsiella pneumoniae from Australia carrying blaNDM-1. Diagn Microbiol Infect Dis 2014; 78: 93-97, doi: 10.1016/j.diagmicrobio.2013.08.001.

14. Islam MA, Huq M, Nabi A, Talukdar PK, Ahmed D, Talukder $\mathrm{KA}$, et al. Occurrence and characterization of multidrugresistant New Delhi metallo-beta-lactamase-1-producing bacteria isolated between 2003 and 2010 in Bangladesh.
J Med Microbiol 2013; 62: 62-68, doi: 10.1099/jmm.0. 048066-0.

15. Kumarasamy K, Kalyanasundaram A. Emergence of Klebsiella pneumoniae isolate co-producing NDM-1 with KPC-2 from India. J Antimicrob Chemother 2012; 67: 243244, doi: 10.1093/jac/dkr431.

16. Bueno MF, Francisco GR, O'Hara JA, de Oliveira Garcia D, Doi Y. Coproduction of $16 S$ rRNA methyltransferase RmtD or RmtG with KPC-2 and CTX-M group extended-spectrum beta-lactamases in Klebsiella pneumoniae. Antimicrob Agents Chemother 2013; 57: 2397-2400, doi: 10.1128/ AAC.02108-12. 